\title{
19 Mapping the Citizen News Landscape: Blurring Boundaries, Promises, Perils, and Beyond
}

\begin{abstract}
This chapter offers a necessary critical overview of citizen journalism in its many forms and shapes, with a focus on its promises and perils and what it means for the future of news. We will start with a review of the concept of "citizen journalism" and its many alternative terms, then move to briefly note the long history of citizen journalism, which dates back to the early days of the printing press. This will be followed by our typology of three major forms of citizen journalism (CJ) - citizen witnessing, oppositional CJ, and expertise-based CJ - along with an assessment of each form's primary actions, motives, functions, and influences. The penultimate part of the chapter will focus on CJ's flaws and pitfalls - especially the mis/disinformation environment it fosters and the "dialogue of the deaf" it engenders - and place them in the context of the post-truth era to highlight the still critical need for professional journalists. The chapter concludes with a brief review of the understandably but unnecessarily uneasy relationship between citizen and professional journalism and calls for the latter to adopt a new attitude to work well with the former.
\end{abstract}

Keywords: citizen journalism, alternative journalism, citizen witnessing, social media, fake news, post-truth

\section{One thing, many labels?}

Within a short time, citizen journalism (CJ) went from something of a novelty to a naturalized part of the news ecosystem and entered the daily language of journalists, journalism educators, and a large segment of the global public. Yet its fluid, pluralistic nature makes it a straightforward task to pin down what exactly it is. Although the prolific body of empirical and theoretical research into CJ continues to expand, with some broad agreement on what it is about, CF is far from a settled concept. This is perhaps in part because it "tries to capture in just two words a complex of shifting and developing capacities and expectations" (Meikle 2014: 174). As Stuart Allan (2013: 8) points out:

discourses of citizen journalism reveal an array of virtues in the opinion of advocates striving to transform journalism by improving its civic contribution to public life - and conceal a multitude of sins in the eyes of critics intent on preserving what they perceive to be the integrity of professional practice - in complex, occasionally contradictory ways. 
This manifests in the wide and rather "dizzy" range of labels that CJ has been given since the late 1990s and early 2000s, when it began to attract wide attention thanks to the rise of weblogs. Some of the labels are associated with the act of publishing (e.g., personal publishing, self-publishing, open publishing, collaborative publishing, participatory publishing, community publishing) while others with a nonmainstream media form (e.g., radical media, social movement media, emancipatory media, thin media, and we-media). Most labels, however, include a journalism component (e.g., do-it-yourself journalism, grassroots journalism, guerrilla journalism, ordinary journalism, hyperlocal journalism, deliberative journalism, distributed journalism, participatory journalism, open/open-source journalism). More recently, some scholars have confined CJ primarily to the act of bearing witness, using terms such as "citizen witnessing” or "eyewitness imagery" (Allan 2013; Mortensen 2014).

"Citizen journalism" as a term itself entered mainstream vocabulary after the Boxing Day tsunami in South Asia in 2004, when professional news outlets found themselves in "the awkward position" of having to rely, for the first time on a massive scale, on raw content contribution from eyewitnesses on the ground (Allan 2013: 9). This prompted the BBC to set up in April 2005 an entity called UserGenerated Content Hub in its newsroom, which quickly gained popularity, expanded, won awards, and inspired a range of other similar initiatives, such as the CNN's iReport and Al Jazeera's Sharek. The increasing acceptance of the "citizen journalism" title thus paralleled that of "user-generated content" (UGC), which became an umbrella term to refer to all kind of content contributed by citizens to news production and dissemination. Although some use UGC and CJ interchangeably, it must be noted that much CJ is not UGC and much UGC (e.g., a tiny, often impulsive comment on a mainstream news story) can be hardly substantive enough to rub shoulders with things that we generally see as CJ - such as fully-fledged eyewitness accounts or blog posts.

Some observers attempt to define CJ by dissociating it from mainstream news media. One example is Jay Rosen's oft-quoted definition - "when the people formerly known as the audience employ the press tools they have in their possession to inform one another, that's citizen journalism". Yet, as already seen, CJ can be done through or in collaboration with, rather than just outside, the mainstream media. Others (Atton 2003, 2009; Forde, Foxwell \& Meadows 2009) subsume CJ under the umbrella of "alternative journalism". For them, although it remains to be seen how online citizen platforms and their emerging journalistic styles would alter audience demands and expectations and the general news landscape, it is safe to place them under the overarching catch-all category of alternative journalism. Under this "infuriatingly vague" blanket term, CJ is seen in the same light as any type of news that falls outside or strays beyond and/or challenges the remits and practices of institutionalized media (Atton 2003). However, as we shall see, not all citizen journalism is "alternative" in that sense - and vice versa. 
In sum, although the above plethora of terms reflects the rich, diverse, and rigorous nature of citizen news, it highlights at least some ambiguities over what counts and does not count as CJ. Indeed, as CJ blurs the boundaries in numerous aspects of human communication, many fundamental questions remain open to wide interpretations. Is CJ simply an act of public participation, a cultural production pros a cultural prod act or a combination of some/all of these? Where is the bordemme between private mformation sharing and personal news publishing, between institutional and ordinary expertise in the news flow, between professionally constructed truth and ordinary consensus, et cetera? More fundamentally, what constitutes "citizen" and "journalism" in CJ? Is CJ just an extension of the old journalism for citizenship model (where citizens, although being active in contributing their own news and views, are at the mercy of professional journalism) or does it represent a new, more radical journalism as citizenship paradigm (journalism exercised by citizens to inform each other beyond the control of the professional media), or both?

\section{A brief note on a long history}

Although CJ is a term of the digital era, the sort of citizen participation that it refers to has a far longer history. For Correia (2012), CJ is the logical second phase of the "public journalism" movement in the US in the late 1980s and 1990s. This was a movement in which mainstream journalism - in attempts to bridge the widening gap between ordinary citizens and between them and governmental institutions opened up some of its space for citizens to create their own news to inform each other, to share interests and concerns, and to reach common values. Barlow (2007: 180) contends that CJ is "simply public journalism removed from the journalism profession" (i.e. without the need for journalists to offer their space and moderation service). Even the idea of the news media creating news-sharing spaces for the oridinary folks is as old as the press. Boczkowski (2004: 141) noted that the first US newspaper, Publick Occurences, Both Foreign and Domestick, published in only one unlicensed issue in 1690, had one "peculiar feature": one of its four pages was left blank for readers to write their news before passing it on to others.

Independent citizen participation in the news flow had an even longer history, dating back to the 16th century, when the newly invented printing press fueled the rise of the pamphleteer journalist in England and France. In the early 1800s and mid-to-late 19th century, a great deal of unpaid, non-professional, and voluntary journalistic work was done in the form of a radical-popular press. From the early 20th century, this radical press responded to the needs of the working classes in socialist movements, a phase that ends with the start of World War II (Forde 2011). After a "lull" period, it "re-emerged, revitalized and took a new face" in the 1960s alongside the rise of counter subcultures (Forde 2011: 36). The 1970s started to see 
cheaper and simpler broadcast production tools, coupled with growing interests in alternative media, arts, and politics, attracting an increasing number of practitioners to small-scale community media, prominently in Western contexts (Atton \& Hamilton 2008; Harcup 2003).

Things, as we have known, took a dramatic turn in the 1990 s thanks to the intrusion of the web and subsequent cheap and easy-publishing tools such as chat rooms, forums, blogs, camcorders, mobile phones with built-in cameras,

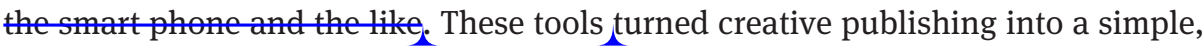
user-friendly process and allowed everybody to easily become a "reporter". As the means of production was now in the hands of ordinary folks, citizen news would sooner or later be part of public life. As Dan Gillmor, the first American professional journalist running a blog, puts it succinctly, "when anyone can be a writer, in the largest sense and for a global audience, many of us will be" (2006: 236). In other words, as Meikle (2014: 175) argues, “the news doesn't just talk to us, but we can now talk back; and perhaps more importantly, we are also now all the more likely to talk to each other about what we're hearing".

Indeed, the new technologies did not have to wait long to show their power. Introduced into the news ecosystem at the time when the world started to face an unprecedented acceleration of terrorism and the war on terrorism experienced an unusual number of human/natural disasters and crisis events, CJ tools quickly established their place in the news landscape thanks in a large part to its unprecedented power to provide witness accounts from the ground,during crisis events of the first half of the 2000 s (more on this below). Today the output of citizen journalism can be seen everywhere on the Internet, with its use in mainstream news being "no longer an occasional exception to the general rule" (Allan \& Peters 2015: 478) and, of course, not limited to crisis events. For the purpose of an overview, the next section will categorize $\mathrm{CJ}$ on the basis of functions and roles, motives and purposes, and contributions to the broader public sphere. From this functional perspective, we observe that $\mathrm{CJ}$ forms fall under three broad conceptually distinctive, although operationally overlapping, groups: citizen witnessing (CJ as accidental journalism), oppositional citizen journalism, and expertise-based citizen journalism.

\section{Citizen witnessing}

Bearing witness, as hinted above, is perhaps the most remarkable, most visible part of the citizen news landscape. Stuart Allan (2013: 9), who introduces the "citizen witnessing" concept, defines it as "first-person reportage in which ordinary individuals temporarily adapt the role of journalists to participate in newsmaking, often spontaneously during a time of crisis, accident, tragedy or disaster when they happen to be present on the scene”. At the center of citizen witnessing is the imperative of eye witnesses to perform a random, spontaneous, journalism-like act. Wit- 
nessing encompasses two distinctive things: observation (the private, passive experience of seeing) and action (the public, active performance of saying) (Mortensen 2014). The main difference between digital and traditional witnessing is that both can now be done by the very same person, who would find it easy, and perhaps tempting at times, to cross the line between observation and action. "Compared to the traditional witness, testimonies have changed profoundly by this figure moving behind the camera and holding the option of uploading pictures almost instantaneously" (Mortensen 2014: 147). This spur-of-the-moment, often emotionally charged first-person reportage is the opposite of professional journalists' dispassionate, impartial, trustworthy, and reliable witnessing and testimony service (Allan 2013).

The potential of citizen witnessing, or "accidental journalism", was noted and heralded from the very early days of the web. Historically, journalists have long been bearing witness on behalf of the public as most people do not have access to - or the resources to access - events of importance to them. However, as John Hiler (2002) argued in the early days of blogging, the "traditional media food chain" has a limited number of participants "with only so many people available to do the original reporting and fact checking" and thus carries with it "consistent bias that fails to reflect the diversity of opinions and ideas". With blogs and other media production tools in their hands, ordinary folk are now close to the event to pick up many things that journalists might miss, and thus can correct that bias. Although professional journalists as "narrators" are still valued, they "will never be as omnipresent as millions of people carrying a cell phone that can record video" (Naím 2007). Long before the arrival of smart phones and social platforms such as Twitter, Facebook and YouTube, Dan Gillmor had envisioned that fifty pictures of a news event could be posted before print or broadcast photographers arrive on the scene (Nguyen 2006).

Gillmor's scenario, considered to be quite radical at the time, would soon turn out to be too modest during the aforementioned Boxing Day tsunami in 2004 and the London bombings in July 2005. Within six hours of the London bombings, for example, the $\mathrm{BBC}$ received more than 1,000 photographs, 20 amateur videos, 4,000 text messages and 20,000 emails from people on the ground, and the next day's main newscast started with an edited version of a user video. That led the BBC to the conclusion that, according to its then Director of News, Helen Boaden (2008), eyewitness accounts were not just "nice to have" but something that would change newsgathering “forever”. Such accounts, she said, open her journalists' and viewers' eyes to not only stories that "we would never have known" but also "a wider diversity of voices than we could otherwise deliver”. Since that watershed event, citizen witnessing has consolidated its place through many crises, disasters and unusual events, such as Mumbai terrorist attacks (2008), Iranian uprisings (2009), Arab Spring series (2010-2011), among many others.

Today, "citizen journalism, in all its different forms and guises, has become such a normalized component of today's media landscape that it is almost a natu- 
ralised expectation" in news about any crisis/disaster event (Thorsen 2014: 141). Witnessing is not confined to relaying images and videos but also live-reporting and live-streaming events to audiences across a number of social and mainstream media platforms. In some cases, citizens lead the media in breaking the news: e.g., Twitter coverage of the airplane landing on the Hudson River in New York in 2009, or the live coverage on social media of street protests and rallies across the Middle East and North America region during the Arab Spring. In other cases, they add testimony materials, witness perspectives, and emotional responses to the news agenda and beyond. Often, as Thorsen (2014) observes from the live reporting of the deadly attacks in Oslo and Utoya by the right-wing Norwegian activist Anders Breivik in 2011, the impact of citizen witnessing is limited to the early hours of a crisis: once the crisis scenario had been established, citizen witnesses were gradually replaced by official sources. Mortensen (2014: 151) quoted Struk (2011) to argue that eyewitness images, because of their decontextualization, usually "prompt stories" rather than "tell stories".

Witnessing accounts are often driven by the desire to share experience and to tell stories. In times of crisis, people flock to social media such as Facebook, Twitter, and Flickr both to bear witness and to engage with events (Ibrahim 2014). For many of CNN's iReporters in the 2009 Iranian uprisings, the desire to voice competing interpretations of events - not money, much less fame (which was potentially dangerous) - was the main driver of their unpaid labor (Palmer 2014). For some, being attached to a global news organization was a source of additional strength as it assures that they were not alone in their hardship. Indeed, through engaging with "imagined communities" and materializing such communities with their own exchange of news and views, citizen witnesses constitute a vital part in the general account of what happens. In most cases, "witnessing becomes part of the event, which changes both the witness's perceptions of the event, the retrospective reconstruction of the event, and at times, even the course of the event itself" (Mortensen 2014: 150). The material provided through the "civilian gaze" (Ibrahim 2014: 19) is especially precious in places where journalists are banned from or have limited access to events (Nguyen 2009; Palmer 2014).

Sometimes the motive is simply to seek or contribute to justice - and does not need to emerge right at the time of the crisis. At 11:30 pm on 1 April 2011, the London Metropolitan Police Service (MPS) announced that a Londoner, Ian Tomlinson, had died in the midst of large violence protests against the G20 Summit. As the MPS continued to paint the cause of his death as natural, eyewitnesses emerged, with images and testimony accounts, to suggest a completely different story. The decisive moment came when the Guardian posted on 7 April the video footage of Tomlinson's last moment, which shows him as a carefree person treading his way home through the crowd and being suddenly struck down to the ground, then swiped with batons and pushed hard in the back by a police officer. The footage was supplied by an American fund manager, Christopher La Jaunie, who decided to hand 
it the press simply because it was, from what he witnessed and filmed, "clear that the family were not getting any answers” (Greer \& McLaughlin 2014: 43).

\section{Oppositional citizen journalism}

If citizen witnessing is about accidental reporting and has much to do with the desire to share experience from the ground, oppositional citizen journalism is practiced as a sustained, non-accidental activity to serve some ideological agendas and causes. Unlike witnessing, the collection and reporting of oppositional news can, and often does, operate on a semi-professional and more organized level that involves both amateurs and trained journalists. Such CJ can be seen as a form of alternative journalism, a concept emerging in the 1970s to refer to news that represents the opinions of small minorities - often with attitudes hostile to widelyheld beliefs - and deals with subjects not given attention in the mainstream media. Oppositional CJ, like other forms of alternative journalism, is practiced from a position of citizenry, communities, and activists - with overt advocacy and oppositional practices (Atton 2003, 2009). Rather than serving as a contribution to mainstream media, oppositional CJ aims to present unspoken voices from below, privileging "the powerless and the marginal" rather than the powerful that define mainstream news (Harcup 2003: 371). As such, oppositional CJ can be seen as a mode of civic movement in which financial capital and skillsets are kept at minimal levels and reporting expertise is less important than political activism.

Although oppositional CJ has been around for a long time, the Internet brought new energy for it to reach out to become an increasingly indispensable news source (Atton 2013). Atton and Hamilton (2008: 79) see this as "the greatest expansion in alternative journalism", attributing it to the fact that "user-driven programmes enable the set-up of websites and discussion groups with minimal technical expertise". Similarly, Forde (2011: 44) saw the Internet as "a site of democratic and socially empowering journalism" and "a key moment in the development of alternative journalism”. In continuity with the past, Forde argues, the Internet can help oppositional journalists, both amateurs and professionals, to "continue to do what their predecessors have always done - use information to challenge, analyse and mobilize” (2011: 176). Such news initiatives "are unquestionably fulfilling an educational and/or mobilizing function" with the broader aim to "transplant this function to a larger audience" (2011: 168). In some cases, they empower people to form a "fifth estate" to act as a watchdog of powerful forces in society, with a primary focus on voices against the cultural and political powers of the day.

An oft-touted example of oppositional CJ is the Korean OhmyNews venture, which was founded in 2002 out of its founder's perception that the Korean media are too conservative to allow for any liberal, progressive politics. What seemed to be an absurd news venture at the time - which combines liberal grassroots report- 
ing with light professional fact-checking, under the "Every citizen is a reporter" motto - quickly became an inspiring success for many around the world. Within less than four years, it built up an army of nearly 30,000 "news guerrillas" and was the country's most influential news site and sixth most influential news outlet (Nguyen 2011). Its advocacy coverage and vital campaign amongst young voters for Roh Moo-Hyun, a little-known anti-establishment "political novice and maverick", was credited as "a, if not the, decisive force" in bringing him to the presidency in the 2002 general election (Nguyen 2011). It was the first news outlet given an interview by the president. Its heyday, however, seems to have been over: although OhmyNews still maintained a 100-strong staff with about 80,000 citizen reporters (as of 2015), it has struggled financially for some time as its once unique model is no longer a novelty and the initial enthusiasm of citizens has waned (Nguyen 2011; Kang 2016). Meanwhile, attempts to repeat its success elsewhere - e.g., OhmyNews Japan, NowPublic in Canada or Assignment Zero and Bayosphere in the US - have failed, and its own international English-language version did not survive, due to a rich range of socio-cultural facilitating factors that are specific to its original country.

Another oft-mentioned example of oppositional CJ is Indymedia. Starting with witness accounts from the street during anti-globalization protests in 1999 in Seattle, Indymedia quickly rose to become a global open-publishing platform where ordinary concerned citizens participate in all aspects of an online media project that campaigns and acts "against the bureaucratic-capitalist state" (Salter 2009: 179). Soon after Seattle, Independent Media Centers (IMCs) spread around the world, with 80 active by 2002 and 175 in 2010. The facility with which multimedia content could be uploaded gave a flexibility not seen in other media platforms, allowing both ordinary citizens and activists to present alternative perspectives to the mainstream press on the events that they covered. The number of IMCs, however, has declined particularly quickly since 2010, with only 66 being counted in 2014. Giraud (2014) attributed this to a long list of problems both internal (informational hierarchies, bureaucracy, inclusivity issues of the global networks) and external (e.g., the rise of social networking sites, the decline in global justice movements). The open-publishing format, with no editing before publication, paved the way for content to go too far from the progressive ideals of Indymedia activists. Indeed, Atton (2003: 70) asked if "(becoming) a contributor by clicking the 'Publish' button is actually harming its attempts at progressive social change”. Also, developing a model that could be financially viable proved to be an impossible task.

Despite the decline of large-scale ventures, oppositional CJ is still alive in the work of many smaller groups or individuals. It remains a vital part of the public sphere, especially in places where there is a perceived "democratic deficit" in mainstream media. Citizen journalists reporting from zones of political instability and warfare or operating under repressive regimes, for example, have risked their 
lives for their determination to provide facts and truths. Ruqia Hassan Mohammed - who used her Facebook account under the pen name of Nisan Ibrahim to report on the "life for residents of Raqqa [Syria], ISIS's Syrian stronghold, and the frequent coalition airstrikes against the group” (Gani \& Shaheen 2016) - was killed by ISIS in September 2015. Citizen journalists operating in the 2010 Haiti earthquake and the 2013 Gezi Park demonstrations in Istanbul revealed that one main reason for them to engage in something that put them at risk (physical harm or prosecution) was to "challenge the monopoly that mainstream media institutions have over agenda setting" and "offer perspectives that often get filtered out in mainstream media (Baruh et al. 2014: 173-174). As Fisher concluded from reflecting on Al Jazeera's interaction with citizen journalists during the Arab Spring, "the days have gone of governments believing that by closing off transmitters or taking over radio and TV stations, of blocking mobile phone signals and satellite TV signals, or shutting down the internet they will somehow win the propaganda battle" because "social media have clearly changed the media landscape - and is playing a part in changing the world" (2011: 158).

The impact of oppositional CJ should be considered beyond crisis and conflict situations. In places where authoritarian rules prevent the media from doing a proper job, disillusionment with official media has led to the birth of many influential alternative citizen news initiatives that keep a close eye on those in powers on a daily basis. In Vietnam, most recent political blockbuster stories - from senior politicians' harrowing incompetence, irresponsibility, corruption, and other misdeeds to top-secret personnel information (e.g., who to leave and to stay in the Politburo of the ruling communist party at its latest national congresses in 2011 and 2016) - have been broken on blogs and Facebook, often many days before they are, if at all, mentioned in the official media. Its former PM, Nguyen Tan Dung, publicly conceded that "we can no longer prevent or ban information on social media”. Similar developments have been recorded under many other authoritarian regimes (see Allan \& Thorsen 2009; Thorsen \& Allan 2014).

\section{Expertise-based citizen journalism}

This category involves ordinary citizens researching, reporting, and writing in nonmainstream media about topics in which they possess some expertise. The public, as Kovach and Rosenstiel (2001) pointed out, is an interlocked body: one might be indifferent to or ignorant of most things but is likely to be passionate and/or knowledgeable about a particular area which they might be willing to take necessary actions to share, promote and/or protect. Expertise-based CJ can be provided by educated experts in some specific subject areas who come to the fore to exercise their "professional citizenship". A scientist, for example, might blog about new research findings in their subject area, share their expert insights into something 
with lay audiences, or voice concerns over professionally unhealthy or questionable issues (e.g., non-scientific motives and/or inadequate standards behind some research work that is in the public domain). Experts, however, do not always need to be people who acquire specialized knowledge/skills from prolonged professional education and experience. Expertise could well be "popular expertise" - i.e. built on experience of living and doing. A veteran resident of a local area might know much about its weather patterns and flower species and want to share that on a hyperlocal news site, a community forum or, more recently, "citizen science” projects initiated by scientific institutions.

Expertise-based CJ is much more prevalent than it might sound. In fact, much of the driving force of the rise of CJ in the 2000s was expertise-based. The early blogosphere was a place primarily for the tech-savvy to discuss new technology and web design, which did not substantially change until the aftermath of September 11 (Hiler 2002). Science topics were soon to join the arena, and, by early 2005, Technorati, a blog monitoring service, was tracking about 700,000 blog posts about science at any one time (cited in McIlwaine \& Nguyen 2005). Meanwhile, Slashdot.org, an early CJ venture that recorded 10 million unique readers each month by its seventh birthday in 2003, is a cooperative "news for nerds" site, where users discuss every complicated topic from the latest software, new cancer treatments to global warming or political moves in space. Numerous concrete examples can be found to show how ordinary people, in developing and developed countries alike, have used the Internet to set up their own science forum, to expose "bad science", to call government science-related responses and policies into question, and so on.

Expertise-based CJ, of course, is not confined to science topics. Early observers of blogs might recall that Dan Rather, the veteran US newscaster, fell from grace after the blogosphere proved wrong a document that he presented on CBS to accuse President George W. Bush, when he was younger, of skipping out on military service. Among their evidence was that the document possessed many typographical elements that a 1970 typewriter would not do, including the Times New Roman font style, proportional spacing, and the "th" superscript (Nguyen 2006, 2008). In Vietnam, within a few years of the country's connection to the global network, a music fan conducted an online investigation to prove that one of its most famous pop composers plagiarized his top songs from a Japanese album (Nguyen 2009). A more recent example is the groundbreaking exposure of Syrian arms trafficking by Leicester-based Eliot Higgins who conducted a purely online investigation and “exposed Syrian arms trafficking from his front room” (Weaver 2013). Every evening, Higgins - an unemployed finance and admin worker who had no experience in a war zone or any specific media training - sifted through and examined meticulous details of about 450 YouTube channels that were uploaded from Syria by all sides of the conflict: activists, rebel brigades, Islamist groups, Assad supporters, and state TV. Under the pseudonym of Brown Moses, he discussed his findings in 
chatroom discussions and was later picked up by the Guardian's Middle East live blog. This mix of citizen reporting from the ground and the self-trained analysis of an unpaid dedicated blogger was commended in the global media and by global agencies such as Amnesty International and Human Rights Watch.

Unfortunately, the potential of expertise-based CJ does not seem to have been appreciated by the mainstream media as fully as citizen witnessing. Knoblich (2013) found it "strange" that, despite initiatives like UGC Hub, iReport, and Sharek, professional journalism does not seem to make rigorous attempts to embrace and engage with $\mathrm{CJ}$ beyond crisis events. "Couldn't citizens bring the same value personal stories, local context, and even volumes of personal data - to nearly any news topic of interest?" he asked. This is, to say the least, a wasted opportunity because, as Gillmor (2006) puts in, "the people at the edges of the communications and social networks", although acting sometimes as "a newsmaker's harshest, most effective critics", can also be "the most fervent and valuable allies, offering ideas to each other and to the newsmaker”. Blogs, for example, often take stories from the mainstream media, dig deeper to find alternative perspectives, challenge facts or enrich them with supplementary materials (Beckett 2008). Indeed, some critics contend that by just (re)broadcasting eye witnessing episodes as fodder content and place holders during crises - often while their crews or affiliates are still on the way to reach the location of an event - the mainstream media have misappropriated the "citizen journalism" label.

\section{The perils of cit-j}

Alongside its empowering potential and democratic promises, CJ has been a source of concerns for many. The citizen news environment, as Clay Shirky (2002) aptly calls it, is a "publish, then filter" - rather than "filter, then publish" - world. For advocates, this brave new world relies on its self-governing and self-righting process. Questions of integrity and truth can be offset by what Pierre Levy calls "collective intelligence" or by the fact that ordinary people often police each other, often with good and healthy motives (Beckett 2008). The blogosphere, for instance, has been defined and promoted as a hypertextual space in which electronic links between and among a wide range of texts and images will lead to a constant shift of networks and thus constant scrutiny of facts and perspectives. In such spaces, as millions of bloggers and social media users constantly monitor, fact check and expose mistakes, the wisdom of the crowd will work, sometimes at its best (Lowrey, Parrott \& Meade 2011; Naím 2007). This is in essence a return to the core of the "freedom of expression" and "free marketplace of ideas" concepts that were the building blocks of the liberal press theory. Siebert, Peterson, and Schramm (1956: 45) summarized this as follows: "Let all with something to say be free to express themselves. The true and sound will survive; the false and unsound will be van- 
quished". The false, in this theory, might gain a temporary victory but the true has the unique power to survive because people, assumed to be rational, know how to reason.

For critics, however, the self-righting process through the wisdom of the crowd does not always work and could sometimes be harmful. The warnings of Rebecca Blood (2002), an early author on blogging - that "the weblog's greatest strength, its uncensored, unmediated, uncontrolled voice, is also its greatest weakness" can well be applied to the entire citizen news sphere. The case of the FindBostonBombers campaign on Reddit in the days after the Boston Marathon bombings in April 2013 - in which a man named Sunil Tripathi was wrongly identified as the perpetrator by a fellow High School classmate - shows how counterproductive CJ could be. As Reddit participants were trying to identify a potential killer, their research became part of the media story. But such research "just turned out to be hopeless, worthless and to some extent harmful" - particularly after images of potential suspects went viral and caused distress (Meikle 2014: 175). Citing Pierre Levy's "collective intelligence" concept, which is built on the premise that "no one knows everything, everyone knows something", Meikle contends that "sometimes no one knows anything” (2014: 172). The case displays two perennial headaches: a) the flood of false information that CJ fosters and b) the "dialogue of the deaf" that it engenders.

\section{1 "Dialogue of the deaf" in the time of "filter bubbles"}

As new "demotic voices" rise in news discourses, there is simultaneously the high risk of citizen news turning into a chaotic place. For one thing, as is often said, too many cooks can spoil the broth: too many voices can overload people with information and lead them to nowhere. In other words, to use another popular saying, when everyone has a megaphone, it is impossible for anyone to be heard. For another, people are not always rational human beings who use reasoning to work out the truth through a self-righting process. Online discussions can become shouting matches, where people do not work toward consensus and are often short-lived, with little impact on the outcome of public affairs. This was clear in the FindBostonBombers campaign, where Scifo and Baruh (2013: 8) observed that the spreading of misinformation and the rush to conclusion were due largely to the "excitement of Reddit users and social media enthusiasts, and the larger public, to find the perpetrators of the bombings". In fact, emotion reigns in much of the digital public sphere where "people now have a shared space and probably some common relationship but there is nothing to guarantee shared values" (Nguyen 2006: 148). The ethics of participatory discourse - e.g., the acknowledgement and articulation of other feelings and values in seeking a universal agreement of moral standards can all too often fall into oblivion. As Altheide (2014: 5) observes, "more information has produced little understanding” because "what governs our mediated exis- 
tence are not facts, historical encounters with context, but rather emotional attachments, opportunities to express feelings, personal views and experiences that can be shared with friends".

Over time, people retreat into their own small world with like-minded people, with the public sphere being fragmented into different "echo chambers": people now have increasingly less chance to be exposed to differences, happily entertaining and indoctrinating themselves with only facts and ideas they agree with. Sadly, such echo chambers have been effectively fostered by Google and Facebook's dominant personalization algorithm, which exposes people to only information relevant to and/or compatible with their personal background, use history, interests and/or values. Eli Pariser (2014) calls the product of such opaque algorithmic personalization "filter bubbles". Like the deaf who cannot hear each other, these ideological and cultural bubbles rarely meet with each other. Their impact on democratic processes could be detrimental, as already seen in recent world-shaking events, such as the British vote to leave the EU and the election of Donald Trump to the US presidency in 2016.

\subsection{Mis/disinformation and the rise of fake news}

The "dialogue of the deaf" is worsened by the sheer volume of false information online. There have been numerous incidents in which citizen journalism goes utterly wrong because citizen journalists have too much autonomy in spreading misinformation (inadvertently false information) and disinformation (purposefully false information). Reviewing live reporting on mainstream and social media during the Mumbai attacks, for example, Ibrahim (2014) found that "valid and inaccurate accounts were ... strung into streams of conversation and information on the event mirroring both new forms of empowerment and vulnerabilities”. In fact, during times of crisis, a great deal of online materials and source claims are very complex and difficult for even respected and resourceful mainstream news outlets to verify, let alone citizen reporters (Thorsen 2014). Falsehood can be found not only in the "amateur web" but also on mainstream news sites that integrate UGC, even though the latter do set guidelines for their users and contributors to adhere to (Beckett 2008).

The threat of digital mis/disinformation has loomed larger since the British EU referendum and the US general election, both of which saw the spectacular rise of "fake news" on social media. As filter bubbles amplify political voices on Facebook and other platforms, social media became a breeding ground for large-scale election hoaxes. As an indicator of their sheer influence, the top 20 false US election stories generated nearly nine million Facebook shares, reactions, and comments, with one claiming that Pope Francis had endorsed Trump being shared nearly one million times (Silverman 2016). Some of these hoaxes are purely to make money through social media advertising, but others were for political gains, such as hyper- 
partisan fake stories from the Breitbart News Network that targeted right-wing, nationalist, anti-migration, anti-globalisation polities. In fact, orchestrated efforts to spread online disinformation for propaganda purposes have been around for a while. In Vietnam and China, for example, armies of trained and state-funded "public opinion agents" have used whatever necessary, including falsehood, to counter/debunk any "bad news" about the political system of the ruling parties. It was, however, shocking when it became a cancer in the most powerful democratic societies. The situation has led some countries to devising strict measures to punish social media for the fake news let through their platforms. In Germany, for every fake story they fail to remove within 24 hours, Facebook and the like could be fined up to 50 million euros.

What is concerning in that context is the disregard for even the basic standards

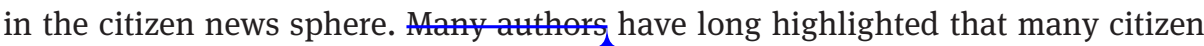
journalists are unaware of - or even hold a contempt for - the fundamental ethics that govern the daily news that they receive from mainstream journalism. This takes many forms - e.g., the lack of ethical considerations in taking and circulating highly graphic and shocking images (Reading 2009) - but of more pertinent interest here is their disregard for fact-checking and source triangulation. Research with citizen journalists who posted during the Haiti earthquake and Gezi Park protests shows how some "might even consider not having to fact-check as an advantage they have over journalists reporting for the news media" (Baruh et al. 2014). Blood (2002) observed the same amongst early bloggers, who were proud of their "no stinkin' fact checkers” attitude "as if inaccuracy were a virtue”. Allan (2013: 94) alse notes that many citizen witnesses are "unapologetically subjective", seeing the rawness, low quality, and emotional charge of citizen witnessing as a virtue in its own right. For them, it offers a vivid, even "more real", alternative to the standardized and packaged professional news coverage that is embedded with too many "bland ... even off-putting" elite notions such as fairness and balance.

To deal with the assault of mis/disinformation on democratic life, attempts have been made to provide citizen journalists with verification tools. As of writing, for example, Silverman's open-access publication, The Verification Handbook (2015), has been translated into several languages for citizen journalists to improve their fact-checking skills and increase the reliability of their work. Given the attitudes discussed above, however, it remains to be seen how such initiatives will be received and used. There is, however, one thing for sure: the need for professional journalism, contrary to what many believe, is not eliminated but is all the more strengthened in the so-called post-truth time. As Alan Fisher (2011: 156) of AlJazeera argues, the material provided by citizen reporters "is simply a commodity" whose value is only gained when added with context. "Real journalism is committed when the facts are gathered, fashioned into a clear narrative and explained the proper contextual framework as part of a larger conversation," he said. In the fight against mis/disinformation, professional journalism can work hand in hand with 
CJ to bring the best of both worlds for the sake of an informed, self-governed citizenry. That is, however, more easily said than done.

\section{Concluding notes}

Many journalists are, understandably, uneasy about the CJ title. It, as Fisher (2011: 156) observes, "sits uncomfortably with some of my colleagues, inferring that somehow their efforts equate to those of trained, experienced journalists". Photojournalist Tlumacki of the Boston Globe is "sick of citizen journalism, which kind of dilutes the real professionals' work” (quoted in Allan 2014: 164). He calls the world to realize that "it is haunting to be a journalist and have to-cover it" and that "we are news photographers, not somebody out there with an iPhone and a camera, jumping over people to put images on YouTube" (Allan 2014). Karen Fratti (2013) of Adweek contends that "citizen journalism is a lofty little term thrown around by interweb idealists" whose values barely move past crisis reporting: "Let's just stop using the term citizen journalist. Call them sources, or hire them as a stringer, and be done with it." Even CNN executives and journalists, while coopting and exploiting the free creative labor poured into iReport, are anxious of their professional monopoly over meaning being hijacked and often use the professional twin concepts of credibility and validity to "simultaneously celebrate and denigrate” iReporters' embodied experience and emotional authenticity (Palmer 2014: 31).

There are also concerns among journalists and scholars that as the news industry co-opts CJ to compensate for its declining resources, its speed and "crass style" presents an attack on professionalism. Shoemaker and Reese (2014) claim that

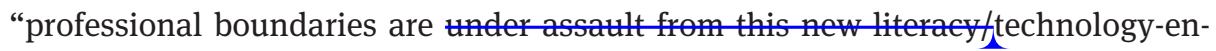
abled citizen journalism". Veteran Guardian investigative journalist David Leigh fears that the "proper reporter" is under threat in the age of the internet. Predicting that "a new model of journalistic production" will be underway in all British national newspapers within the year, he warned that the "patient assembler of facts" faces being replaced in the future with "hyper-active news bunnies". From a historical perspective, however, one might wonder whether such worries are necessary or even helpful. Journalism and its standards have always evolved in the past and will continue to do so in the future - alongside social developments and technological advances. Rather than dismissing CJ or seeing it as a rival, as Singer (2015) argues, journalists have to "come out of their shell from behind the article" to engage with the public in genuine ways and to "redefine their own practices and processes". Journalists need to wake up to the fact that journalism can no longer be an elite group of well-trained and educated professionals that stands apart from others, but is very much part of an interconnected world with interrelated prac- 
tices. Conceiving journalism in the narrow context of the traditional newsroom is not a sustainable way into the future.

\section{Further reading}

For an authoritative account on citizen witnessing, see Citizen Witnessing (Allan 2013). To seek historical and critical perspectives as well as empirical studies on the rise of $\mathrm{CJ}$ around the world, Citizen Journalism: Global Perspectives (Allan and Thorsen 2009 and Thorsen and Allan 2014) would serve as excellent starting points. Susan Forde's Challenging the News (2011) provides much food for thoughts about the potential power of oppositional citizen journalism. Full details of these books can be found in the reference list.

\section{References}

Allan, Stuart. 2013. Citizen Witnessing: Revisioning Journalism in Times of Crisis. Cambridge: Polity Press.

Allan, Stuart. 2014. Reformulating photojournalism: interweaving professional and citizen photoreportage of the Boston bombings. In Einar Thorsen \& Stuart Allan (eds.), Citizen Journalism: Global Perspectives. Volume 2, 155-170. New York: Peter Lang.

Allan, Stuart \& Chris Peters. 2015. The public eye or 'disaster tourists': investigating public perceptions of citizen smartphone imagery. Digital Journalism 3(4). 477-494.

Allan, Stuart \& Einar Thorsen (eds.). 2009. Citizen Journalism: Global Perspectives. New York: Peter Lang.

Altheide, David. 2014. Media Edge: Media Logic and Social Reality. New York: Peter Lang.

Atton, Chis. 2003. What is 'alternative journalism'? Journalism 4(3). 267-400.

Atton, Chris. 2009. Alternative journalism: ideology and practice. In Allan Stuart (ed.), The Routledge Companion to News and Journalism Studies, 169-178. London: Routledge.

Atton, Chris. 2013. Alternative media, the mundane and 'everyday citizenship'. In Matt Ratto \&

Wrong page number??? Typo, 53?

Pl. add date of last access

Pl. add date of last access.

Pl. add date of last access. Megan Boler (eds.), DIY Citizenship: Critical Making and Social Media, 343- (3) Cambridge, MA: MIT Press.

Atton, Chris \& James Hamilton. 2008. Alternative Journalism. London: Sage

Barlow, Aaron. 2007. The Rise of the Blogosphere. Westport: Praeger Publishers.

Baruh, L., Alex Papadimitriou, Zeynep Günel, Haluk Mert Bal, Yusuf Salman, Salvatore Scifo \& Büşra Çildaş. 2014. Deliverable D4.1.2: Final report on citizens' involvement in emergency communication, available at http://cosmic-project.eu/sites/default/files/deliverables/

Beckett, Charl.p. So8. Supermedia: Saving Journalism So It Can Save the World. Oxford: Blackwell.

Blood, Rebecca. 2002. The Weblog Handbook, available at Whttp://www.rebeccablood.net/ handbook/excerpts/weblog_ethics.html

Boaden, Helen. 2008. The role of citizen journatrsm in modern democracy. BBC Online, 13 November. Available from: of_citizen_journalism.htm

Boczkowski, Pablo. 2004. Digitrumy the News: Innovation in Online Newspapers. Cambridge, MA: MIT Press. 
Correia, Joao Carlos. 2012. Online journalism and civic life. In Eugenia Siapera \& Andreas Veglis (eds.), The Handbook of Global Online journalism, 101-118. West-Sussex: Wiley-Blackwell.

Fisher, Alan. 2011. The Arab Spring, social media and Al Jazeera. In John Mair \& Richard Lance Keeble (eds.), Mirage in the Desert? Reporting the "Arab Spring", 149-159. Suffolk: Abramis.

Forde, Susan. 2011. Challenging the News: The Journalism of Alternative and Community Media, Basingstoke: Palgrave Macmillan.

Forde, Susan, Kerry Foxwell \& Michael Meadows. 2009. Developing Dialogues. Indigenous and ethnic community broadcasting in Australia. Bristol: Intellect.

Fratti, Karen. 2003. The problem with citizen journalism. Adweek. May 10, available at

Pl. add date of last access. $\mathrm{Pl}$. add date of last access.

Pl. add date of last access.

Pl. add date of last access.

Pl. add date of access. 口ttp://www.adweek.com/digital/problemwithcitizenjournalism/

Gani, Aisha \& Shaheen, Kareem. 2016. Journalist Ruqia Hassan murde so Isis after writing on life in Raqqa. The Guardian, 5 January, available at ahttp./Wnww.theguardian.com/world/ 2016/jan/05/journalist-ruqia-hassan-killed-isis-raqqa-syri 2

Gillmor, Dan. 2006. We the Media: Grassroots Journalism By the People, For the People. Cambridge: O’Reilly.

Giraud, Eva. 2014. Has radical participatory online media really 'failed'? Indymedia and its legacies. Convergence 20(4). 419-437.

Greer, Chris \& Eugene Mclaughlin. 2014. Righting wrongs: citizen journalism and the miscarriages of justice. In Einar Thorsen \& Stuart Allan (eds.), Citizen Journalism: Global Perspectives. Volume 2, 39-50. New York: Peter Lang.

Harcup, Tony. 2003. The unspoken - said: the journalism of alternative media. Journalism 4(3). 356-76

Hiler, John. 2002. Blogosphere: the emerging media ecosystem. Available at ahttps:// tinyurl.com/y826c8yq

Ibrahim, Yasmin. 2014. Sod. Einar Thorsen \& Stuart Allan (eds.), Citizen Journalism: Global Perspectives. Volume 2, 15-26. New York: Peter Lang.

Kang, Inkyu. 2016. Web 2.0, UGC and citizen journalism: revisiting South Korea's OhmyNews model in the age of social media. Telematics and Informatics 33. 546-556.

Knoblich, Trevor. 2013. Can citizen journalism move beyond crisis reporting? MediaShift, May 13.

Available at http://mediashift.org/2013/05/can-citizen-journalism-move-beyond-crisisreporting127

Kovach, Bill \& Tom Rosenstiel. 2001. The Elements of Journalism. New York: Three Rivers Press.

Lowrey, W., S. Parrott \& T. Meade. 2011. When blogs become organizations. Journalism. 12(3). 243-259.

Mcllwaine, Stephen \& An Nguyen. 2005. Science, journalism, technology and democracy. Journalism and the Public: Refereed Proceedings of Journalism Education Association Conference, Gold Coast, December 1-3.

Meikle, Graham. 2014. Citizen journalism, strarmg and the ethics of visibility. In Einar Thorsen \& Stuart Allan (eds.), pp. 171-183. New York: Peter Lang.

Mortensen, Mette. 2014. Eyewitness images as a genre of crisis reporting. In Einar Thorsen \& Stuart Allan (eds.), Citizen Journalism: Global Perspectives. Volume 2, 143-154. New York: Peter Lang.

Naím, Moises. 2007. The YouTube effect. Foreign Policy 158. 103-104.

Nguyen, An. 2006. Journalism in the wake of participatory publishing. Australian Journalism Review 28(1). 143-155.

Nguyen, An. 2008. The Penetration of Online News: Past, Present \& Future. Saarbrücken: VDM Verlag.

Nguyen, An. 2009. Globalisation, citizen journalism and the nation- state: A Vietnamese perspective. In Stuart Allan \& Einar Thorsen (eds.), Citizen Journalism: Global Perspectives, 153-162. New York: Peter Lang. 
Pl. add date of last access.

Pl. add date of last access. Pl. write out the full first names Pl. add date of last access. Pl. add date of last access. Write out the full first name Full first name

Pl. write out the full first name Pl. add the date of last access.
Nguyen, An. 2011. Marrying the professional to the amateur: strategies and implications of the OhmyNews model. In Graham Meikle \& Guy Redden (eds.), News Online: Transformation and Continuities, 195-209, Basingstoke: Palgrave Macmillan.

Palmer, Linsay. 2014. CNN's citizen journalism platform: the ambivalent labour of iReporting. In Einar Thorsen \& Stuart Allan (eds.), Citizen Journalism: Global Perspectives. Volume 2, 27-38. New York: Peter Lang.

Pariser, Eli. 2014. The Filter Bubble. New York: Penguin Books.

Reading, Anna. 2009. Mobile witnessing: Ethics and the camera phone in the 'war on terror'. Globalizations 6(1). 61-76.

Redden, Guy, Nicholas Caldwell \& An Nguyen. 2003. War-blogging as social critical practice. Southern Review 36(2). 68-79.

Salter, Lee. 2009. Indymedia and the law: issues for citizen journalism. In Stuart Allan and Einar Thorsen (eds.) Citizen journalism: global perspectives, 175-186. New York: Peter Lang.

Scifo, Salvatore \& Lemi Baruh. 2013. Deliverable D2.3: Report on the adverse use and reliability of

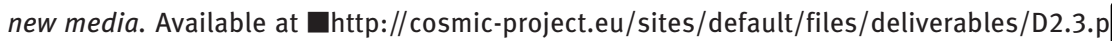

Siebert, Fred, Theodore Peterson \& Wilbur Schramm. 1956. Four Theories of the Press. Urbana: University of Illinois Press.

Shirky, Clay. 2002. Broadcast institutions, community values. Available at http://www.shirky.com/writings/broadcast_and_community.html

Shoemaker, DP. J. \& S. D. Rees 14 . Mediating the Message in the $21^{\text {st }}$ Century. New York: Routledge.

Silverman, Craig. 2015. The Verification Handbook. Available at $\square$ http:// verificationhandbook.com/book/

Silverman, Craig. 2016. This analysis s how viral fake election news stories outperformed real news on Facebook. BuzzFeed, November 26. Available at: Dhttps://tinyurl.com/ ybsbnmq6

Singer, Jane. 2015. Out of Bounds: Professional Norms as Boundary Markers. In 7 arlson \& . Lewis (eds.), Boundaries of Journalism: Professionalism, Practices and Turicipation, 2 6. Oxford: Routledge.

Struk, Janina. 2011. Private Pictures: Soldiers' Inside Views of War. London: I. B. Tauris.

Thorsen, Einar. 2014. Live reporting terror: remediating citizen crisis communication. In Einar Thorsen \& Stuart Allan (eds.), Citizen Journalism: Global Perspectives. Volume 2, 127-142. New York: Peter Lang.

Thorsen, Einar \& Stuart Allan (eds.). 2014. Citizen Journalism: Global Perspectives. Volume 2. New York: Peter Lang.

Weaver, 013 . How Brown Moses exposed Syrian arms trafficking from his front room. The Guan 21 March, available at $\square$ https://tinyurl.com/y6vhtdhe

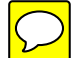

